\title{
The Responsibilities and Obligations of STS in a Moment of Post-Truth Demagoguery
}

\author{
STEVE G. HOFFMAN ${ }^{1}$ \\ UNIVERSITY OF TORONTO
}

\begin{abstract}
Scientific expertise and the free press have come under sustained partisan attack with the political ascendance of right-wing nationalism. This has put some science and technology studies (STS) scholars in the difficult position of defending the legitimacy of science while maintaining a characteristic agnosticism toward "the facts." In this essay, inspired by a reading of Noortje Marres's (2018) critique of fact-checking services, I seek to relieve some of the background anxiety I sense that perhaps STS research paved a path for the rise of right wing authoritarianism and "post-truth" politics. We are not dealing with a process of fact making in this environment, at least not of the scientific variety. Instead, we are dealing with political demagoguery. As scholars, we should therefore equip ourselves with the appropriate analytic and technological tools, and as many as possible, for engaging this political moment.
\end{abstract}

\section{Keywords}

authoritarianism; demagoguery; fact checking; knowledge democracy; post-truth; scientific facts

\section{Introduction}

Conservative populism mixed with a vengeful brand of white supremacy is making political headway across Europe and North America (Bonikowski 2017; Bhambra 2017; Gidron and Hall 2017). The European Union is in peril, trade wars are underway, the United Nations is under assault, and longstanding geo-political alliances in place among the Western democracies since World War II are up in the air. Meanwhile, political pundits and commentators warn us of another "constitutional crisis" on the horizon, seeming to forget the previous one as the news cycle moves on. Established scientific institutions and the free press in the United States are being actively de-legitimated. A climate change denialist, Scott Pruitt, who once called for the abolishment of the US Environmental Protection Agency (EPA), now runs it. Despite news reports that document his wasteful spending, conflicts of interest, and corruption, or perhaps because of these practices, President Donald Trump thinks he is doing a heck of a job. Trump

Steve G. Hoffman, Email: steve.hoffman@utoronto.ca 
even declared war on the free press with a tweet, soon after taking office, stating "the FAKE NEWS media...is the enemy of the American People." Yet the very same outlets that Trump declared to be the enemies of the republic have boosted their sales by repeating his lies, boasts, and misdirection (Lakoff and Duran 2018). This has had the effect of further amplifying his dog whistles to white supremacists, overt discrimination against members of LGBTQ and Muslim communities, distain for the United Nations and accords aimed at reducing greenhouse gas emissions, cover ups and obstructions of lawful investigations, insults of global allies, wistful praise for authoritarian leaders, regressive economic policies, admitted sexual predation, and haphazardly rolled out and inhumane crackdowns on immigrants and their children.

What is this topsy-turvy we have entered? How can we be at a place in our politics where it is protest to claim that $2+2=4$ ?

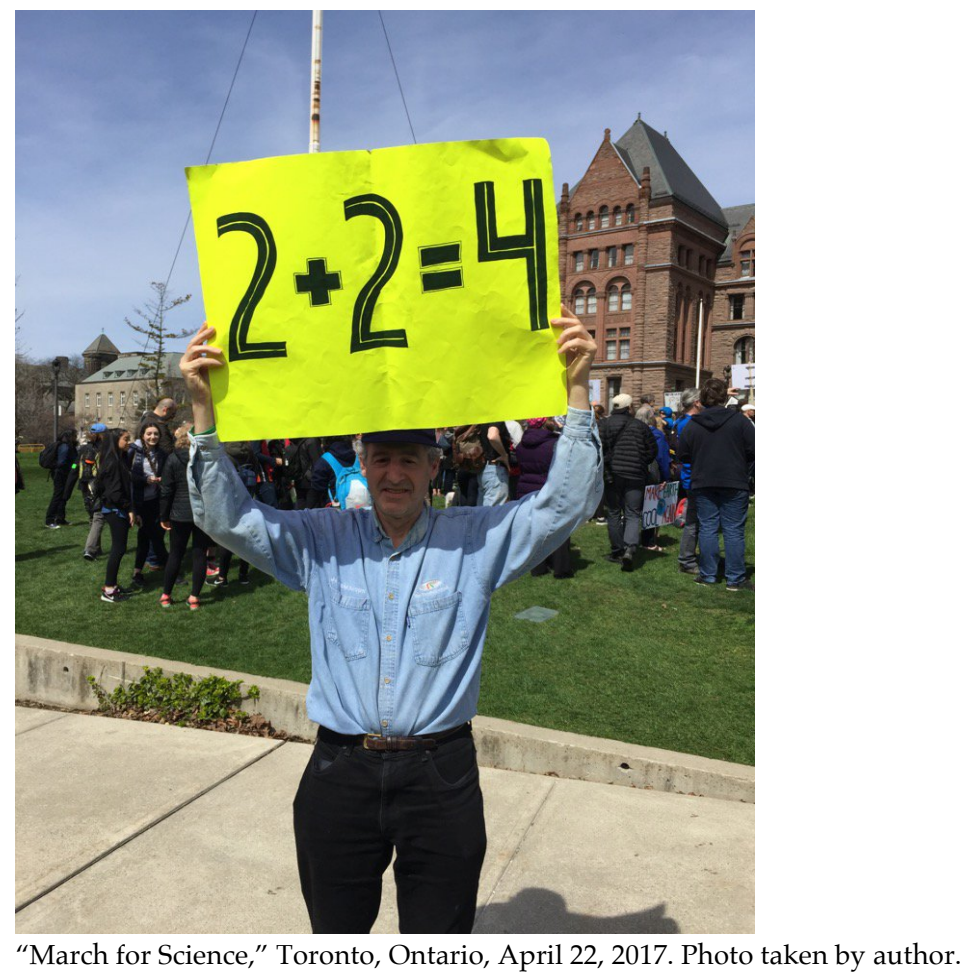

Who can be faulted for hoping that a few facts might pull us out of this upside down world? Maybe, hope against hope, a few clear lines of demarcation can get us back to some semblance of reality.

In this essay, inspired by a reading of Noortje Marres's (2018) critique of fact-checking services, I seek to relieve some of the background anxiety I sense that perhaps STS research paved a path for the rise of right wing authoritarianism. I argue that we are not dealing with a process of fact making in this environment, at least not of the scientific variety. Instead, we are 
dealing with political demagoguery. As scholars, we should therefore equip ourselves with the appropriate analytic and technological tools, and as many as possible, for engaging this political moment.

\section{STS, Facts, and Fact Checking}

The problem for STS scholars is that a cornerstone of our shared field is a certain kind of skepticism toward scientific authority and expertise. We have seen too much, been too close, and delved too deep to blindly embrace "facts" as a solution to disorder. Where most see facts, we see settled claims and black boxes. We remain unconvinced by an updated correspondence theory of truth-the notion that the strength of facts is measured by the degree of overlap with a reality that exists before, after, outside, or otherwise beyond the processes and infrastructures that produce knowledge claims. It is not merely the institutional authority of scientific institutions and expertise that matters (although, clearly, they can and do), but also the conditions under which knowledge gets produced, disseminated, and put to use. STS is rooted, then, in its own form of populism. We are the champions of "knowledge democracy" and "citizen scientists."

Can STS maintain a constructivist orientation toward "facts" and expertise while also defending scientific institutions and evidence-based reasoning from the attacks of reactionary plutocrats and authoritarians? Or, has our poking and prodding at the authority of science paved a path for right-wing authoritarianism?

These are the background concerns animating Noortje Marres's (2018) thoughtful article on why we can't have our facts back in a moment of post-truth politics (see also Jasanoff and Simmet 2017; Lynch 2017; Sismondo 2017). Marres argues that the prolific array of tools and services for correcting "fake news," internet rumors, and politician's misleading statements represent a nostalgia for a never-existed time of science before politicization, an idealist fantasy where scientific facts determined the bandwidth of acceptable political discourse. Fact-checking efforts, she suggests, yield an overreliance on technical expertise that distracts our attention from the more thoroughgoing "crisis of public evidence in today's computationally-intensive societies" (423). These technologies displace attention from the "technologies of source selection that regulate content circulation online" (431), reinforce problematic and all-too-easy normative boundaries between true and false, trustworthy and untrustworthy, knowing and unknowing, worthy and unworthy, etc., and do little to remedy the problem that we tend to live in ideologically homogenous social media enclaves.

Marres's essay is most vital when it documents the limits of algorithmic selection processes built into fact-checking technologies like Factmata and Facebook's Disputed Source. Similarly, her discussion of the behaviorist assumptions underpinning the design of social media architectures is an important reminder that right-wing populists did not invent opinion manipulation nor its current technological modalities. These are excellent examples of using the conceptual vocabulary of STS to reveal how various technologies of information, knowledge, and truth are deeply implicated in current geo-political crises. Where the critical intervention is less clear, however, is around whether or not these technologies yield a zero-sum game that short 
circuits democratic engagement. I, for one, see fact checkers as an inevitably partial but still useful tool for resisting authoritarianism. They are clearly having a moment that STS scholars ought to document. Regardless, my main point is that as we debate abstractions like the politics of demarcation, epistemic democratization, and the normative boundaries of knowledge claims, Trump and his acolytes are burning down the house.

Marres's concerns about a "return" to a politics of demarcation comes across a bit detached from the immediacy of the moment. The critique of fact-checking services, for example, inches toward practical implications but, on the whole, does not arrive at a concrete enough place to provide guidance for dealing with the increasingly frequent moments that demand an immediate response. I am just not sure what it means, practically speaking, to "replace a retrospective with a dynamic conception of the role of empirical truth in public debate" (434). Sounds good, but if a "dynamic conception... of empirical truth" includes a place for the sorts of "alternative facts" that the Counselor to President Trump, Kellyanne Conway, propagandizes, or other conspiracy theories that embolden white supremacists and gun-toting vigilantes, or a border policy that systematically separates babies and young children from their parents, then I must pass. I have come to appreciate the efforts of The New York Times, Washington Post, and other fact-checking journalism efforts when they provide some accuracy amid the flurry of lies, deceptions, and misdirects spread on social networks, right-wing media, and by the current occupant of the White House. Marres is correct to point out that fact-checking services are but an ointment atop a much worse infection. Yes, reliance on fact checking can, over the long haul, distract our attention from the dilemmas rooted in the way that information is structured and disseminated on the Internet. In the meantime, however, fact checking efforts are a much used and largely useful modality for cutting through the purposive confusion sown by Trump's "gaslighting" governance strategy (see Keane 2018 for a helpful explication of this term). It is, indeed, a problem that fact-checking services are rarely read by the people who believe the lies. But, if fixing all the problems with the Internet and social media infrastructures, and all at once, is the only way forward, we will be standing still while the house burns.

\section{Why STS is Not Responsible for this Mess}

I sensed a subtle misapprehension running through Marres's analysis as it relates to the responsibilities and obligations of STS in this political moment. STS scholars are neither responsible for, nor increasingly inclined to adjudicate, scientific facts. In fact, STS scholarship has never had much to say about the truth status of facts at all. The vast majority of STS research is "ontographic" (Lynch 2013), not ontological. The best empirical research in STS evinces a deep agnosticism toward "the truth." We are quite good at watching how truth gets produced precisely because we leave aside what it is. We document how boundaries of truth are produced, and we do so partly by limiting the imposition of our own. STS has effectively demonstrated that facts are not inherently impactful. I may resolve the empirical uncertainties of string theory in my basement, but unless I can figure out how to disseminate my findings and convince others of their veracity and importance, my results are neither knowledge nor fact. From that standpoint, I 
do not think there is much to the concern that a "politics of demarcation" is on the rise within STS circles or scholarship. Furthermore, demarcation never really went anywhere outside of constructivist intellectual circles, anyway.

It is from this position that I think we can safely relieve ourselves of a lingering sense of guilt that perhaps our questioning of scientific authority paved the way for the rise of right-wing authoritarianism. We did not create this mess, for much the same reason that postmodern theory is the wrong whipping post (Perrin 2017; Der Derian 2017). The technological infrastructures so nicely documented in Marres's work are part of, but do not exhaust, the story. This mess, especially in the US, but with serious global implications, is the culmination of an over threedecades long, very well-funded, and highly organized conservative campaign to foster an alternative fact-making universe constructed by conservative think tanks, lobbyists, media outlets, and professional science deniers whose goal has long been to create generalized distrust in mainstream institutions, free press journalism, professional scientists, and higher education (Jacques et al. 2008; McCright and Dunlap 2011; Oreskes and Conway 2011). Although public trust in science has not declined in the aggregate, the alternative universe campaign has been a rousing success among self-reported conservatives and regular church attendees in the US (Gauchat 2012; Gauchat 2011).

This is the alternative fact-making ecosystem that provided the flora and fauna for Trump's brand of politics and from which his supporters continue to ground their truth claims. Russian troll farms that exploited a media ecosystem characterized by partisan enclaves factored in as well, but the cultivation of an audience highly receptive to their hoaxes and misdirection was part of a longer, larger, deeper, and largely domestic campaign of mystification and propaganda. To be clear, this has almost no resemblance to the scientific fact making practices that STS scholars have so painstakingly opened up. Sergio Sismondo (2017: 3) addressed this point in his Social Studies of Science editorial on post-truth politics:

Embracing epistemic democratization does not mean a wholesale cheapening of technoscientific knowledge in the process. STS's detailed accounts of the construction of knowledge show that it requires infrastructure, effort, ingenuity and validation structures. Our arguments that 'it could be otherwise' (e.g. Woolgar and Lezaun 2013) are very rarely that 'it could easily be otherwise'; instead, they point to other possible infrastructures, efforts, ingenuity and validation structures. That doesn't look at all like post-truth. A Twitter account alone does not make what we have been calling knowledge...If the posttruth era starts by blowing up current knowledge structures, then it isn't very likely to be democratization, and in fact most likely leads to authoritarianism.

In the efforts of STS scholars to prove their mutual imbrication, it has become easy to neglect the ways that science and politics appeal to quite different repertoires of justification. Politics, like infectious disease, runs hot. An effective politician mobilizes the persuasive power of emotion and charisma by pitting one class faction against another. While re-reading Karl Marx's "The 18" Brumaire of Louis Bonaparte" for my graduate theory seminar, for example, it struck me just how many of the strategic moves made by Bonaparte to gain a majority of the 
popular vote in the lead up to the French coup d'état of 1851 echoes Trump's recent rise to power. Alluding to a problem with the politics of demarcation that Marres worries about in our current era, Marx wrote at the time, "The bourgeoisie, to be sure, is bound to fear the stupidity of the masses, as long as they remain conservative, and the insight of the masses, as soon as they become revolutionary" (Marx 1978 [1852]: 517). It remains to be seen if Trump declares himself "Prince-President" like Bonaparte did (we should not put it past him), but Marx's history of the episode provides a reminder that politics as such is not a domain that adheres much to "truthiness." Science, by contrast, tends to run in a cooler and more calculated fashion. Effective scientists mobilize the persuasive power of methodological rigor and the armaments of past research (Latour 1987). This is one reason why the vast majority of politicians come from business and the legal profession, not science.

\section{The Rise of Post-Truth Demagoguery}

Figures like Trump maintain a key advantage over much of their opposition. They are not playing a game of fact making. They have no qualm with making stuff up and then bending the world into the image of the lie. Consider the right-wing cooptation of the term "fake news." In the initial 2016 election conception, "fake news" was a term used to describe fabricated news stories deliberately intended to deceive readers. Examples included the so-called "Pizzagate" pseudo-scandal and the Seth Rich Democratic National Committee conspiracy theory (which both had real-world horrors in their consequences). Shortly after the 2016 Presidential Election, Breitbart News was the first to coopt the term by labeling reports of Russian attempts to influence the US election as "left-wing fake news." Rush Limbaugh then picked up the theme by claiming, "fake news is the everyday news." Soon after, President Trump refused a question from CNN reporter Jim Acosta at his first official press conference by scolding, "Not you. You are fake news." Over the last year, the term has become common parlance among dictators and authoritarians around the globe, with documented cases of leaders in Syria, China, the Philippines, Venezuela, Myanmar, Russia, Uganda, Somaliland, Turkey, Singapore, and elsewhere all finding in the term a convenient way to dismiss and discredit critical reporting on their atrocities and human rights violations (Schwartz 2017).

What we have been describing with the euphemism of "post-truth politics," then, is very far from what STS scholars describe as fact making. Instead, it is demagoguery. Consider the main characteristics of demagogues proposed by James Fenimore Cooper back in 1838. First, the demagogue identifies with the "common people" by mobilizing outrage against an elite in society that is taking advantage of them. Second, the demagogue generates a visceral connection with his or her followers by inflaming anger and resentment, typically against marginalized and / or minority communities. They direct this anger and resentment, however, toward personal ambitions (e.g. "I alone can fix it"). Finally, the demagogue engages in a concerted effort to create confusion in order to break down established norms of conduct, institutions, and the law. Sounds a lot America's 45 President to me. 
Conceiving this as a moment of demagoguery rather than fact making should help cut through some clutter. At the very least, it enables a clearer reckoning with the phenomenon we are facing. STS has had a lot to say about scientific controversies, techniques of replication, consensus building, the ways that scientific institutions maintain credibility or lose it, issues related to the production of legitimacy and authority, and, more generally, the way that politics and power are deeply interwoven into the production and dissemination of scientific facts and technological developments. The process we are used to looking at for producing scientific facts, however, does not look all that similar to what Trump, the National Front in France, the Party for Freedom in the Netherlands, the UK Independence Party, or Alternative for Germany have been up to. Unfortunately, STS scholars have little practiced expertise in studying the work of demagogues. This is, however, the phenomenon that is getting tagged when people say we want our facts back. We better figure out how to study it.

No, we can't have the facts back because we never had them in the first place. But we don't need them. What we need, and what we already have, are sharp analytic and practical tools for documenting the ways that particular technologies of truth are mobilized to produce one sort of world and not others. Sometimes this is done through methodological rigor, consensus building, and by playing with "experimental facts" (Latour 1999). Other times it is done through deception, sowing confusion, the repetition of lies, fear mongering, communicative oversaturation, gaslighting, and coercion. Scientists typically practice the former set of tactics. Demagogues are really good at the latter. What is at stake in our current moment is not so much scientific expertise, per se, but how these tactics of persuasion are being mobilized to grab power. Our responsibilities to the facts in a moment of post-truth demagoguery is to delineate what kinds of knowledge claims get enrolled in the process and which are castigated, dismissed, and silenced. More importantly, we can show how the "facts" of the case, alternative or otherwise, get built, disseminated, and used. Our obligations to the facts are to document their effects on the world building process.

\section{Conclusion}

We get no distant perch from which to observe. What is an appropriate response cannot be decided beyond, before, or outside a political situation. Sometimes it will be appropriate to be highly critical of the ways that "evidence-based policymaking" silences a local citizenry. In those cases, we might champion the citizen scientists, be they mothers protecting their children from industry pollutants (Brown 1992) or commercial beekeepers trying to provide a more grounded picture of a disorder than that provided by academic toxicologists (Kleinman and Suryanarayanan 2013). In other cases, however, it may be appropriate to critically analyze the utter lack of evidence-based policymaking, such as that informing the current regulatory rollbacks at the EPA. I greatly appreciate Marres's suggestion for developing "less judgmental ways of carving up public issue spaces"(438) such as tools that can show how the circulation of hoaxes and misleading stories cluster around serious problems like standards of living and public services. Simply telling people they are wrong to believe in a hoax does nothing to grapple 
with their lived struggles. The common theme across these engagements is not an analytically consistent position vis-a-vis evidence-based policymaking, or an unwavering commitment to epistemic democratization. The common theme is careful empirical attention both to the ways in which knowledge claims are mobilized by politicians, policymakers, and laypersons, and to the effects that those mobilizations have on lived experience. In short, our analytic focus is well tuned when it documents how knowledge, scientific or otherwise, gets used to serve particular institutional interests, agendas, and actors.

STS scholarship has yielded a thick understanding of the processes through which facts get produced and disseminated. At a time when plutocrats are seeking to bend facts to benefit their particular interests, an STS approach to fact-making is a strength, not a liability. Facts take a tremendous amount of work to produce. They do not conform easily to the whims of demagogues and liars. Remaining consistent in our scholarly orientation to vague abstractions like "generalized symmetry," "knowledge democracy," or "demarcationism" has its place, but this strikes me as decidedly secondary to the more pressing work of engaging the current political moment. STS is well-equipped to document the efforts of the demagogues trying to recreate the world in their gaudy image. In the face of these efforts, I do not think we should retreat to a nostalgia for a mystical place where the facts spoke for themselves. Yet let's also not get too bogged down criticizing fact-checking and related practices that are aimed at holding those in power accountable for their words and deeds. Instead, let's use our hard-earned tools, and as many as possible, to expose the poverty of their efforts.

\section{Author Biography}

Steve G. Hoffman (PhD Northwestern) is Assistant Professor of Sociology at the University of Toronto. His research focuses on the cultural politics of knowledge production, with recent articles appearing in Sociological Forum, Science, Technology, \& Human Values, Politics \& Society, and Social Studies of Science. He is currently developing a project about how disaster and emergency managers use simulation to craft knowledge about past and future catastrophe. He teaches

courses on social and sociological theory, science and technology, the sociology of disaster, and cultural politics.

\section{References}

Bhambra, G.K. (2017) "Brexit, Trump, and 'methodological whiteness': on the misrecognition of race and class." The British Journal of Sociology 68: S214-S232.

Bonikowski, B. (2017) "Ethno-nationalist populism and the mobilization of collective resentment." The British Journal of Sociology 68: S181-S213.

Brown, P. (1992) "Popular Epidemiology and Toxic Waste Contamination: Lay and Professional Ways of Knowing." Journal of Health and Social Behavior 33: 267-281. 
Cooper, James Fennimore. (1838) The American Democrat: Or, Hints on the Social and Civic Relations of the United States of America. Cooperstown, NY: H. and E. Phinney.

Der Derian, J. (2017) "Trump demands a post-post-truth response." The Conversation: Canada Edition. Toronto, Ontario: Academic Journalism Society.

Garfinkel, H. (1967) Studies in Ethnomethodology, Englewood Cliffs, NJ: Prentice Hall.

Gauchat, G. (2011) "The cultural authority of science: Public trust and acceptance of organized science." Public Understanding of Science 20: 751-770.

Gauchat, G. (2012) "Politicization of science in the public sphere a study of public trust in the United States, 1974 to 2010." American Sociological Review 77: 167-187.

Gidron, N. and Hall P.A. (2017) "The Politics of Social Status: Economic and Cultural Roots of the Populist Right." British Journal of Sociology 68: S57-S84.

Jacques, P.J., Dunlap R.E. and Freeman M. (2008) "The organisation of denial: Conservative think tanks and environmental scepticism." Environmental Politics 17: 349-385.

Jasanoff, S. and Simmet H.R. (2017) "No funeral bells: public reason in a 'post-truth'age." Social Studies of Science 47: 751-770.

Keane J. (2018) "Post-truth politics and why the antidote isn't simply 'fact-checking' and truth." The Conversation: Canada Edition. Toronto, Ontario: Academic Journalism Society.

Kleinman, D.L. and Suryanarayanan S. (2013) Dying bees and the social production of ignorance. Science, Technology, \& Human Values 38: 492-517.

Lakoff, G.P. and Duran G. (2018) "Trump has turned words into weapons. And he's winning the linguistic war." The Guardian: International Edition. Guardian News and Media Limited.

Latour, B. (1987) Science in Action, Princeton, NJ: Princeton University Press.

Latour, B. (1999) "Give me a laboratory and I will raise the world." In: Biagioli M. (ed) The science studies reader. New York, NY: Routledge, 258-275.

Lynch, M. (2017) "STS, symmetry and post-truth." Social Studies of Science 47: 593-599.

Marres, N. (2018) "Why We Can't Have Our Facts Back." Engaging Science, Technology, \& Society 4.

Marx, K. (1978 [1852]) "The Eighteenth Brumaire of Louis Napoleon. " In: Tucker RC (ed) The Marx Engels Reader, Volume 2. New York City, NY: W.W. Norton \& Company.

McCright, A.M. and Dunlap R.E. (2011) "The politicization of climate change and polarization in the American public's views of global warming, 2001-2010." The Sociological Quarterly 52: 155-194.

Oreskes, N. and Conway E.M. (2011) Merchants of Doubt: How a handful of scientists obscured the truth on issues from tobacco smoke to global warming: Bloomsbury Publishing USA.

Perrin, A.J. (2017) "Stop Blaming Postmodernism for Post-Truth Politics." The Chronicle of Higher Education.

Schwartz, J. (2017) "Trump's 'fake news' mantra a hit with despots." Politico. Politico LLC.

Sismondo, S. (2017) "Post-truth?" Social Studies of Science 47, no. 1 (2017): 3-6. SAGE Publications Sage UK: London, England.

Woolgar, S. and Lezaun J. (2013) "The wrong bin bag: A turn to ontology in science and technology studies?" Social Studies of Science 43: 321-340. 